\title{
Strategy Research on University Construction of Art Practice Educating Innovation Entrepreneurship Base
}

\author{
Yan Liang \\ School of Art and Design \\ Lanzhou Jiaotong University \\ Lanzhou, Gansu, China 730070
}

\author{
Diansheng Guo \\ School of Art and Design \\ Lanzhou Jiaotong University \\ Lanzhou, Gansu, China 730070
}

\begin{abstract}
Lanzhou Jiaotong University builds art design practice educating innovation base and further improves work ideas, method and development strategy of university construction of art practice educating innovation and entrepreneurship base in the aspects of experiment teaching system, experiment team, management mode, innovative talent cultivation and so on.
\end{abstract}

Keywords-educating; entrepreneurship; strategy

\section{INTRODUCTION}

In terms of the essential task of morality education and core target of improving college students' innovation practice ability, we should stick to common target, co-construction of mechanism, resource sharing and responsibility shared by all. We should effectively integrate resources, give play to agglomeration effect, push forward deep integration, constantly summarize, explore and construct, further strengthen construction of "college students innovation and entrepreneurship incubation base", practically improve students' innovative spirit, entrepreneurship sense and innovation and entrepreneurship ability, positively give play to leading effect of demonstration, guide students at school in innovation and entrepreneurship, forge art practice educating innovation entrepreneurship base into explosion place of students' innovative and entrepreneurial mindset and inspiration, comply with requirement of industrial development and encourage students to develop comprehensively in innovation and entrepreneurship.

\section{CuRRENT Status AND TREND OF RESEARCh AT Home AND ABROAD AT PRESENT}

Construction of university art practice educating innovation entrepreneurship base is the multi-layer and comprehensive transformation process of college education reform. Entrepreneurship is inevitable requirement and main sign of development of educating innovation base. Since putting forward of college art practice educating innovation entrepreneurship base, there are thousands of core journal articles and articles on leading newspapers about research on it, which can be concluded in several aspects as follows:

Natural science fund program of Gansu Province " human motion capture system integration based on micromechanics sensor and MotionBuilder" (Project approval No.: 145RJZA032); “The 12th five-year plan” planning topic of educational science in Gansu Province(Topic register No.: GS[2015]GHB0188); Lanzhou Jiaotong University youth science fund research project(Project No.: 2014060.

\section{A. Fundamental Research on College Art Practice Educating Innovation Entrepreneurship Base Construction}

Main perspectives are: Firstly, establish understanding of long-term mechanism based on guiding ideology, system and mode of practical educating. Interpret reform direction of educating base from the perspective of type, level and gradual diversified structure of trained personnel supply in colleges and universities (Shen Jiyun, 2012). Practical educating at school is an education and teaching activity with butterfly effect and strong complexity, covering a wide range. It is necessary to break through currently existed thinking model and frame and determine overall grasp thinking model in order to push forward practical educating with whole process and whole cover comprehensively(Wu Gang and Chen Guixiang, 2013). Establishing long-term mechanism of college practical educating is core proposition of college practical educating and is also useful exploring of college educating mode (Tang Qihua, 2013). Secondly, stand on interpretation of effective construction of educating base. In July, 2015, Ministry of Education, Ministry of Human Resources and Social Security and State Asset Regulatory Commission jointly hold an on-site boost seminar of national universities and colleges practical educating and innovation entrepreneurship in Huanggang, Hubei. The seminar emphasizes on implementation of Party Central Committee's and State Council's strategic deployment concerning practical educating and innovation entrepreneurship, learning from experienced practice of Huanggang City and making efforts to initiate a new situation for college practical educating and innovation entrepreneurship work(New Course Research, 2015).

\section{B. Research on Construction Approaches of College Art Practice Educating Innovation Entrepreneurship Base}

Scholars mainly start from connotation and significance, mode, current status and problems, new mode exploration, system and mechanism construction and guarantee of college and society and industry cooperative practice educating. It is an important topic to combine education with productive labor. Cooperative educating is the core of operation of social practice educating. College practice educating develops to some extent, but seeing from a large range, with development of market economy and arrival of popularization of higher education, internet and information era, realizing practice cooperative educating meets some new challenges and 
opportunities. Put forward interactive platform, operational mechanism and important links which must be grasped of college cooperative practice educating system and constructing principle and important measures of establishing a long-term mechanism through exploration in construction of cooperative practice educating new mode system at the present stage. Constructing college and social cooperative educating has great boost effect on current students' social practice and society's benign development, thus it has deep significance (Wang Xiucheng, 2014).

\section{Comparative Research on Construction of Art Practice Educating Innovation Entrepreneurship Base and Other Educating Bases}

As to differences between college art practice educating innovation entrepreneurship base and other educating bases, domestic academic circle mainly starts from uniqueness of art educating practice base itself, its distinction against student art troupe, art college and professional troupe and its combination of four major functions of talent cultivation, scientific research, social service and cultural inheritance and innovation. All kinds of work in the base is both teaching and scientific research; service and spreading; They experience unified planning under guidance and respectively have features with all flowers blooming together; They can take charge of a department alone to build brand and go abroad to do external exchange (Song Xinyang and Liu Hao, 2015).

\section{Overseas Study}

Scholars' research on China's college art practice educating innovation entrepreneurship base is very limited and they lay particular stress on its global significance. For instance, John Dewey, a foreign scholar, uses concepts of "democracy and education" and so on to explain two kinds of different thinking mode and survival mode at home and abroad. There is obvious difference in practical educating (John Dewey, 2013).

In conclusion, muti-layer and multi-angle are obvious features of research on China's college art practice educating innovation entrepreneurship base construction in academic circle: Research on philosophy, culturology, sociology and pedagogy. Due to different perspectives of research, there are different theoretical directions and theoretical styles: There is mental analysis of philosophy, sensibility of culture, reality of sociology, rigorousness of pedagogy and so on and so forth. Art practice educating innovation entrepreneurship base construction research has great theoretical containment, and this kind of specialty deserves our research. At present, there is lack of deep research on development mechanism and strategy of art practice educating innovation entrepreneurship base in academic circle. We are not satisfied with general research which lacks problem targeted. We plan to stand on "college art practice educating innovation entrepreneurship base development strategy" on the basis of referring to and rethinking the above research results to answer a few questions: What is the targeted problem of putting forward of college art practice educating innovation entrepreneurship base development strategy in educational field? What is its effect on innovation of teaching? How is its effect mechanism and development strategy?

\section{RESEARCH ON GENERAL FRAMEWORK}

Assess current status of domestic college art practice educating innovation entrepreneurship base construction. According to evaluation index of practice educating base construction and collected result of multi-level questionnaire inquiry, analyze on various aspects of current college art practice educating base construction, like establishing new experiment teaching idea, making clear experiment teaching location and reform idea, establishing a practice teaching system with students as the subject of self-innovation, combination of experiment teaching and applied practice and innovation entrepreneurship incubation. Assess transition system crisis encountered by practice educating base in rapid development process. Analyze realistic requirement of art practice educating base for new development mechanism. "Six-in-one" coordination balanced development is the realistic requirement of development of college art practice educating innovation entrepreneurship base. This research aims to demonstrate importance, necessity and urgency of establishing a new development mechanism in construction process of practice educating base on the basis of deep analysis on educating base's positive boost effect on various constructions of college teaching, innovation, competition, producing, learning, research and so on.

Explore methodology of new development mechanism strategy in construction process of art educating base. Clear up various viewpoints of educating base development in recent years and several most representative methodologies of developing educating base. Namely, stress on "multiple-effect innovation" of content and "practical explanation" of essence. Carefully compare and objectively remark above viewpoints and lay a good methodology foundation for reasonable forming of development strategy under new mechanism of art practice educating innovation entrepreneurship base.

Determine drive system of college practice teaching reform in development process of establishing a new mechanism for art practice innovation educating base. Three drive systems are to be determined:

- Self-purge system. Stress on taking "six-in-one" as the entry point and reference point, and promote selfawakening, self reflection and self establishing in development of art practice innovation educating base in order to adapt to requirement of social and industry development.

- Excitation system. Stress on inspiration of enthusiasm of new mechanism and new strategy in adapting to development requirement of society and industry in construction of art practice educating base.

- Industry operation system. Stress on deploying multilateral cooperation and organic renewal and effectively pushing forward construction of art practice innovation educating base to adapt to requirement of industry development. 
Art practice innovation educating base construction complies with new strategy in development process of industry. On the basis of disintegrating respective work principle and workflow of three major drive systems, establish a set of "endogenous" dynamic development mechanism and guarantee regular interaction and sustainable win-in between development of practice educating base and complying with industry requirement to the uttermost.

\section{KeY POINTS AND DifFICULT POINTS IN BREAKTHROUGH}

\section{A. Key Points in Breakthrough}

Apply new development ideas of college art practice educating innovation entrepreneurship base, refer to relatively mature functional theory of educating base construction, compare with example and actual effect of international college educating base construction practice, and analyze comprehensively and systematically on prominent problems faced by domestic college art practice educating base construction. Make comments on practical aspect of existed various defects in function display of constant perfection and complying with industry requirement of college art practice educating base construction. Make reasonable and feasible analysis on strategy system completing and perfecting development of college art practice educating innovation entrepreneurship base. Reasonably design strategy system completing and perfecting development of college art practice educating innovation entrepreneurship base on the basis of systematic analysis on leading function of national college model educating base and put forward strategy schemes with application value for solving practical problems.

\section{B. Difficult Points in Breakthrough}

Art practice and art entrepreneurship are still controversial concepts. The multiplier theory model based on which we conduct research of this topic mainly comes from research results of other domestic professional innovation educating bases. Analysis object is development of college educating base in recent years which can be observed in China. Many prominent new problems in development of China's current college practice educating innovation entrepreneurship base may be not covered and interpreted by its theory model. Practice educating innovation entrepreneurship base construction theory which really belongs to art itself with strong persuasiveness is not mature. What's more, there is big difference between basis and corresponding development strategy design of different professional educating bases. Therefore, rationality and blind spot of its decision-making process are relatively complex and diversified. It will greatly hinder us making accurate identification and maybe change our judging results. We should particularly pay attention to it and treat it with caution in topic research.

\section{RESEARCH THOUGHT AND RESEARCH METHOD}

\section{A. Research Thought "Fig. 1"}

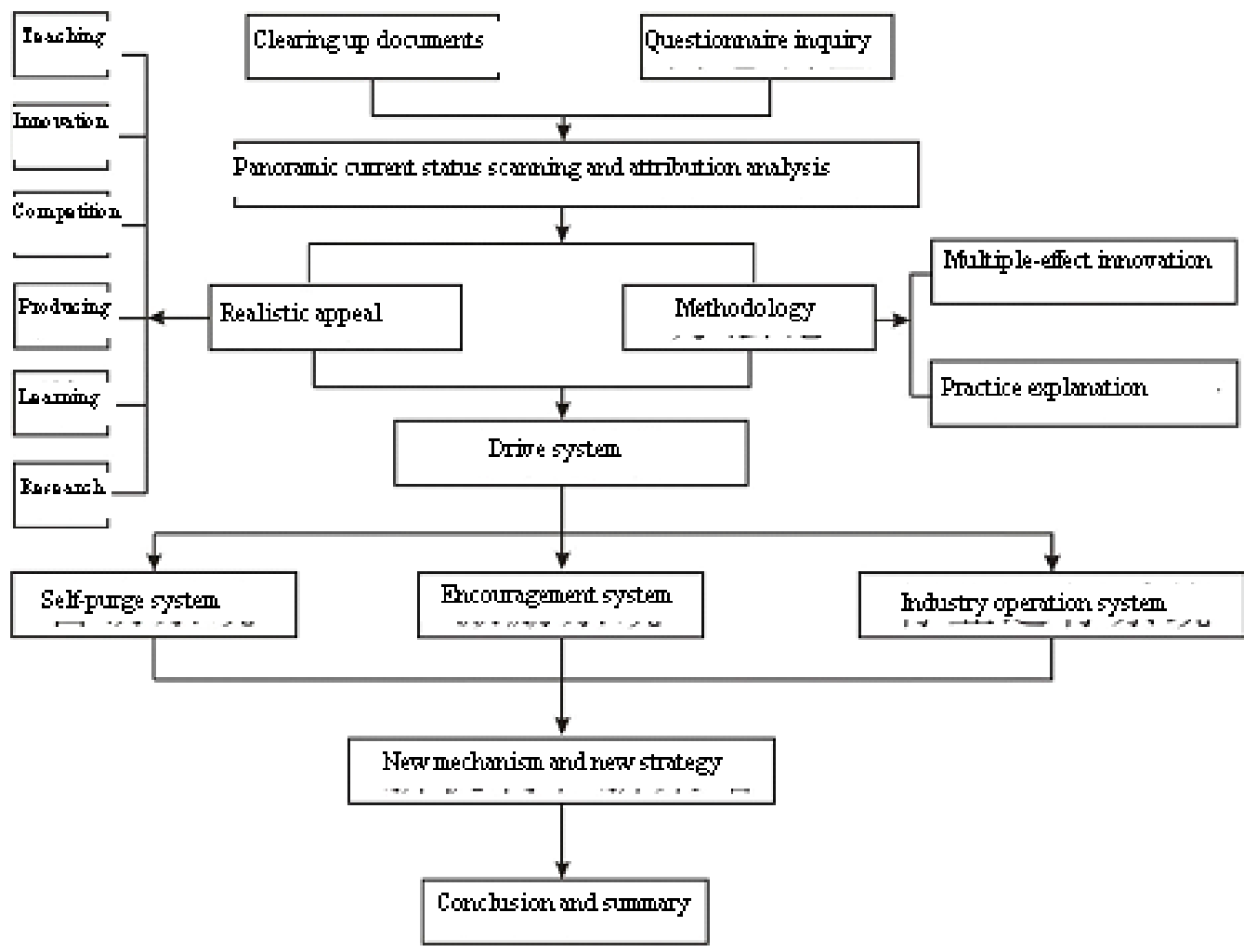

Fig. 1. Research Thought 


\section{B. Research Approach}

1) Combination method of document analysis and investigation: Widely look up relevant various document materials, news report, survey report, statistics material and academic works of college art practice educating innovation entrepreneurship base development strategy at home and abroad. Have a primary understanding of development situation of domestic college art practice educating innovation entrepreneurship base and clear up attribution of current development status of college art practice educating innovation entrepreneurship base in theory through comparison and clearing up documents.

2) System analysis method: Make a deep research on the ways suitable for new strategy of college art practice educating innovation entrepreneurship base. Use criticized soak-up method, organic renewal method, digestion reproduction method and so on. Use systematic thought to face realistic appeal and anticipate long-term future development.

3) Questionnaire method: Firstly, multiple-tier questionnaire. Design of questionnaire is partial to dominant ideology of educating base and survey on actual performance. Secondly, random selection questionnaire. It stresses on negative hindering elements and positive promotion elements of new strategy.

4) Case analysis method: Select typical case of domestic college relevant professional educating base mode with excellent development momentum to conduct analysis in order to reveal optimization selection of domestic educating base mode and look for operational and sustainable developmental mode.

5) Depth interview method: Mainly take theoretical attribution analysis and actual attribution analysis obtained through questionnaire inquiry as interview topic. Consult relevant experts in colleges and research institution and seek theoretical support for element design of new mechanism and new strategy.

\section{CONCLUSION}

Perfect mode theory of new strategy of constructing college art practice educating innovation entrepreneurship base, form theoretical support normal form of educating innovation entrepreneurship base development with Chinese features and provide basis for college reform and college students' innovation and entrepreneurship. It is useful for strengthening effectiveness of college art practice educating innovation entrepreneurship base construction, establishing new mechanism and new strategy of sustainable development and further enriching theoretical arsenal of general rule of college student practice educating base development. Actual application value of research will constitute a set of greatly operational and sustainable dynamic development mechanism and provide beneficial guidance of strategy innovation on dynamic mechanism for colleges to further perfect art practice educating innovation entrepreneurship base; and provide practice support for government to push forward reform of college art educating base.

\section{REFERENCES}

[1] Lu Guodong. Strengthening Process and Deepening Interaction Teaching Method Reform[M].Hangzhou: Zhejiang University Press, 2013.

[2] Zhong Zhixian. College Teaching Mode Reform[M].Beijing: Education Science Press, 2008.

[3] Zheng Tianchi. Graduate Job-hunting Ability Evaluation Method Research[D].Beijing: Beijing Jiaotong University, 2011:20-35.

[4] Xu Tao, etc. Basic Experiment Teaching Center Operation Mechanism and Management Mode[J].Laboratory Investigation and Exploration, 2008,27 (6): 141-142.

[5] Wang Huang. High Level Construction of Experiment Teaching Demonstration Center and Comprehensively Improving Talent Cultivation Quality[J].Chinese Higher Education, 2009, (6) : 17-18.

[6] Yang Yuqiang, etc. Strengthening Experiment Teaching Demonstration Center Construction and Comprehensively Push Forward Laboratory Opening[J].Laboratory Research and Exploration, 2007 (11) .

[7] Li Hongyang, etc. College Experiment Teaching Demonstration Center Construction and Innovative Talent Cultivation[J].Experiment Technology and Management, 2010,27 (9) : 111-114

[8] Qin Gangnian, etc. Innovative Talent Cultivation and Experiment Teaching Demonstration Center Construction[J].Laboratory Research and Exploration, 2007,29 (9) : 116-118

[9] Xie Junlin, etc. Deepening Reform and Innovation Practice Teaching Demonstration Center Construction[J].Laboratory Research and Exploration, 2013,2 (32) : 124.

[10] Li Zhongyun, etc. Science and Education Integration, Collaboration Educating and Improving Talent Cultivation Quality[J].Chinese Universities Technology, 2012 (9) : 6-8

[11] Wu Jianqiang. Exploration and Practice of Experiment Teaching Evaluation Mode under Total Opening and Autonomous Learning Mode[J].Chinese University Education, 2011.04:70-72

[12] Li Yan, etc. Practice Teaching System under Opening and Autonomous Learning Mode[J].Laboratory Research and Exploration, 2012,31 (1): 134-137 